\title{
Upwelling as a Source of Nutrients for the Great Barrier Reef Ecosystems: A Solution to Darwin's Question?
}

\author{
John C. Andrews and Patrick Gentien \\ Australian Institute of Marine Science, Townsville 4810, Queensland, Australia
}

\begin{abstract}
The Great Barrier Reef shelf ecosystem is examined for nutrient enrichment from within the seasonal thermocline of the adjacent Coral Sea using moored current and temperature recorders and chemical data from a year of hydrology cruises at 3 to $5 \mathrm{wk}$ intervals. The East Australian Current is found to pulsate in strength over the continental slope with a period near $90 \mathrm{~d}$ and to pump cold, saline, nutrient rich water up the slope to the shelf break. The nutrients are then pumped inshore in a bottom Ekman layer forced by periodic reversals in the longshore wind component. The period of this cycle is 12 to $25 \mathrm{~d}$ in summer ( $30 \mathrm{~d}$ year round average) and the bottom surges have an alternating onshoreoffshore speed up to $10 \mathrm{~cm} \mathrm{~s}^{-1}$. Upwelling intrusions tend to be confined near the bottom and phytoplankton development quickly takes place inshore of the shelf break. There are return surface flows which preserve the mass budget and carry silicate rich Lagoon water offshore while nitrogen rich shelf break water is carried onshore. Upwelling intrusions penetrate across the entire zone of reefs, but rarely into the Lagoon. Nutrition is delivered out of the shelf thermocline to the living coral of reefs by localised upwelling induced by the reefs. Bottom chlorophyll concentrations average $0.4 \mathrm{mg} \mathrm{m}^{-3}$ at the inner reefs and $0.8 \mathrm{mg} \mathrm{m} \mathrm{m}^{-3}$ near the shelf break while surface concentrations average $0.3 \mathrm{mg} \mathrm{m}^{-3}$; annual top and bottom variances are respectively 0.5 and $1.9 \mathrm{mg} \mathrm{m}^{-3}$ and there is no apparent seasonal cycle. The estimated onshore nitrogen flux in a $10 \mathrm{~m}$ thick bottom layer gives an annual nitrogen input of $20 \mathrm{\mu g}$ at $\mathrm{l}^{-1}$ throughout the water column in a $50 \mathrm{~km}$ zone of reefs, an enormous value for tropical waters.
\end{abstract}

\section{INTRODUCTION}

The geological origins of coral reefs, outstanding ecological anomalies in the oligotrophic surface waters of intertropical seas, were first put into a logical perspective by Charles Darwin (1842). Together with R. A. Daly's (1934) theory of glacial control, Darwin's subsidence theory provides the conceptual frame on which modern theories of reef growth over geological time are founded. In a discussion of conditions favouring reef growth Darwin stated his belief that reef building organisms would be promoted by specialised nutrition processes and concluded 'On the other hand, the polypifers in their turn must prey on some other organic beings; the decrease of which from any cause, would cause a proportionate destruction of the living coral. The relations therefore, which determine the formation of reefs on any shore, by the vigorous growth of the efficient kinds of coral must be very complex, and with our imperfect knowledge quite inexplicable'.
Studies of coral reef metabolism have since been largely concerned with inorganic nutrient cycling within reefs without much attention to the exchanges with the nutrient depleted surrounding surface waters. Central to all reef ecology theories is the coral-zooxanthellae symbiosis which constitutes Darwin's (1933) 'myriad of tiny architects'. Yonge and Nicholls (1931) and Pomeroy and Kuenzler (1969) show this symbiosis is most efficient in conserving inorganic nutrients like phosphorus and nitrogen. This engenders the view that reefs are largely independent of their oligotrophic environment (e. g. Kinsey, 1982). As a corollary of this autonomy, ecologists tend to put reefs in a black box, study them from inside the box and ignore exchanges with the surrounding ocean. On the time scales on which these studies are done the approach is valid and reef building organisms have consequently been quantified as primary producers. Their morphology and capacity to absorb particulate nutrients from surrounding waters is established as well (Lewis, 1976: 
corals as suspension feeders; Reiswig, 1971: sponges; McCloskey and Chesher, 1971: corals and fish faeces) although their nutritional requirements in terms of predation have not been quantified. The inevitable flow of nutritional energy to and from reefs, or any assemblage of them, forces us to consider Darwin's statement and to seek the source of dissolved and particulate nutrients which both promote growth and offset losses in living reefs.

During 1980/81 we carried out an investigation of water mass structure and dynamics, and of nutrient fluxes in a segment of the Great Barrier Reef to see if significant amounts of nutrients from within the deepsea thermocline were supplied to the reefs. The Great Barrier Reef is the largest assemblage of living reefs. It separates a shelf 'Lagoon' from the western Coral Sea (Pickard, 1977). Very little is known about the dynamics of water motion there or about nutrient sources. The East Australian Current flows poleward on the eastern side of the reefs (Scully-Power, 1973) but according to Pickard it has been little studied off the Queensland shelf. Arguments have been made for (Maxwell, 1968) and against (Brandon, 1973) upwelling as a nutrient source but without substantial evidence either way. However, regions of prolific reef growth are correlated with increasing steepness of the continental slope (Maxwell and Swinchatt, 1970). This suggests upwelling on theoretical grounds as Garrett (1979) and Janowitz and Pietrafesa (1980) have shown that the upwelling amplitude depends on the configuration of the shelf and slope. In the British Museum expedition of 1928/29, A. P. Orr (1933) observed elevated bottom water density in the Lagoon, created by deep-sea intrusions, and observed nutrient enrichment at the shelf break. He noted, 'A factor which may be of importance here is the upwelling of deep water rich in plant salts close to the Barrier. When stations close to the Barrier were worked the upwelling was noticeable, especially when the gradient of the sea floor was very steep'.

A priori we expected to find some upwelling on the basis of Orr's observations and the similarity between the dynamics of the eastern shelves of Australia and USA, both of which have western boundary currents on their flanks. Intrusions of cold, bottom water were recognized off USA in 1944 by Green (1944) and have been variously attributed. Atkinson (1977) believes Gulf Stream meanders force the intrusions while Stefansson et al. (1971) present an equally plausible case for wind forcing of the intrusions. Blanton (1971) shows there is evidence for both mechanisms in observational data. Theoretical models do not clarify the situation since intrusions are equally well explained by models of meanders (Garrett, 1979) or of wind forcing (Janowitz and Pietrafesa, 1980). The relative roles of winds and boundary currents require elucidation.

The intrusions off USA are nutrient rich and have a major effect on phytoplankton development (Dunstan and Atkinson, 1976). They initiate dense phytoplankton blooms and large increases of zooplankton (Atkinson et al., 1978). Rochford (1972, 1975) found that similar upwelling intrusions on the south east Australian shelf were a regular feature in spring and summer. These produce elevated nitrate levels up to $4-6 \mu \mathrm{g}$ at $1^{-1}$. He examined the occurrence of upwelling intrusions in relation to coastal winds, longshore currents and topography but was unable to find any causal relationships.

The a priori evidence suggested our investigation could answer 4 questions: Does nutrient enrichment occur? If so is it caused by meanders of the East Australian Current or by wind forcing (or both)? Is there any evidence that the nutritional status of the shelf ecosystems is enhanced by upwelling? Can we quantify this enrichment to assess the importance of upwelling for the reefs of the Great Barrier Reef?

\section{METHODS}

Our study area was a rectangle at $18.5^{\circ} \mathrm{S}, 125 \mathrm{~km}$ along the reefs and $90 \mathrm{~km}$ across from the Lagoon to the deep-sea (Fig. 1). We sampled the water column at the stations indicated on 12 cruises during 1980/81, approximately once a month for a year. Temperature, thermometric depth, salinity, $\mathrm{NO}_{3}, \mathrm{NH}_{4}, \mathrm{O}_{2}, \mathrm{Chl}-\mathrm{a}$ and $\mathrm{PO}_{4}$ were measured at standard depths with Niskin casts to the bottom or $750 \mathrm{~m}$ depth. These data were taken to show some instantaneous (relatively speaking) distributions of nutrients, salinity and temperature, as well as to monitor the strength of the East Australian Current over the continental slope. Distributions of nutrients and thermohaline data are classically used to trace upwelling. The CSIRO supplied data from 4 limited cruises as well. Aanderaa current meters were moored in $55 \mathrm{~m}$ depth of water for $50 \mathrm{~d}$ in summer at a site just seaward of the Lagoon edge (near Rib Reef; Fig. 1) and at a site midway between the Lagoon edge and the shelf break (near Pith Reef; Fig. 1) for $95 \mathrm{~d}$ also in summer. Each mooring carried a meter, measuring also water temperature, $10 \mathrm{~m}$ below the surface and $10 \mathrm{~m}$ above the sea floor. These data were collected to see if intrusions in summer of the sort described by Rochford $(1972,1975)$ could be detected as far inshore as the outer Lagoon.

Temperatures were measured with a recording thermistor for $185 \mathrm{~d}$ spanning winter and including the period of the summer mooring, at the bottom of a $20 \mathrm{~m}$ deep, $100 \mathrm{~m}$ diameter hole in the reef flat of a centrally 


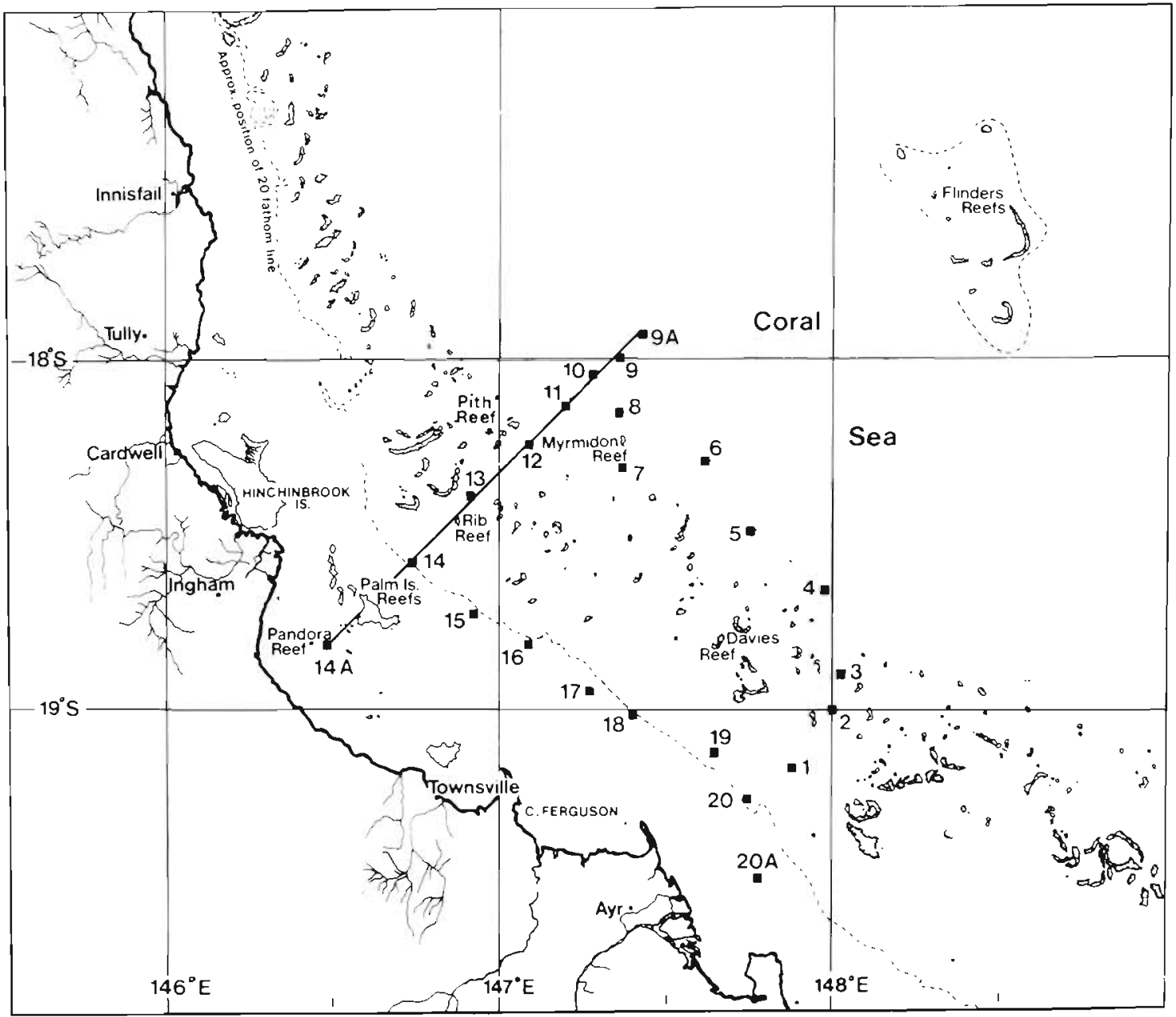

Fig. 1. Locality diagram showing regular hydrology monitoring stations, the transect line for Fig. 3, and slope monitor stations (10 and 11) for Fig. 2

placed reef (Davies Reef; Fig. 1). These data were collected to see if the upwelling intrusions were of large or small scale (if the cold intrusions were correlated from Pith to Davies reefs or not), to see if they persisted throughout the year or were merely a summer phenomenon and to see if the intrusions actually reached the living coral of reef flats, and therefore of the whole reef. Winds were recorded at 9 am and $3 \mathrm{pm}$ at Cape Cleveland lighthouse (near Cape Ferguson; Fig. 1) and were averaged to reduce diumal effects. These data were gathered to investigate the relationship between wind forcing and upwelling intrusions.

We do not intend to present all of the data here or to describe its many facets. An analysis of the ocean response to wind forcing, using cross spectral analysis techniques has been given by Andrews (1982) and a description of the thermohaline structure and water chemistry of the outer shelf and slope will be given elsewhere. The data presented here are abstracted from the total set to allow an interpretation of shelf water enrichment by upwelling intrusions, an interpretation of the cause of the intrusions themselves and an estimation of their importance for the shelf ecosystems.

\section{RESULTS}

\section{The Outer Shelf and Slope}

The first question is whether the East Australian Current (or its eddies, filaments or meanders) creates an upwelling-favourable climate near the shelf. We are not concerned with the exact mechanism perturbing the current since the central question (Atkinson, 1977; Garrett, 1979) is only whether the current over the continental slope intensifies. A poleward geostrophic current will bend horizontal property surfaces upwards towards the shelf and a convenient represen- 
tation of current strength is the horizontal temperature gradient at $240 \mathrm{~m}$ depth (Hamon, 1968). In Fig. 2 we present the temperature differences, oxygen deficit

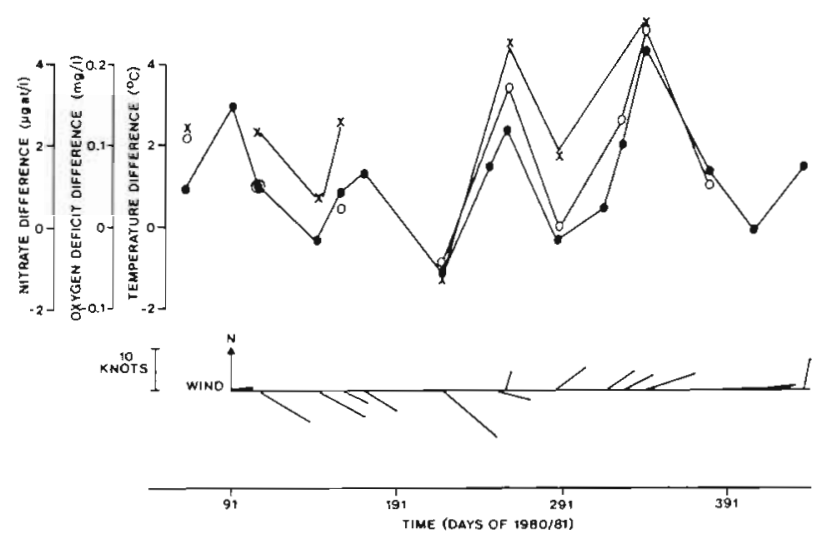

Fig. 2. Time series of temperature difference (dots) and oxygen deficit difference (circles) at $240 \mathrm{~m}$ depth between 2 monitor stations (10 and 11) over the continental slope at $18^{\circ} 10^{\prime} \mathrm{S}$. Crosses show a more limited series of nitrate differences. Wind vectors are averaged for $8 \mathrm{~d}$ around each sample time differences and nitrate differences at $240 \mathrm{~m}$ depth over $10 \mathrm{~km}$ between 2 monitor stations on a line perpendicular to the slope isobaths. A rise in temperature difference accompanies a waxing of the current over the slope while the correlated rises in the differences in oxygen deficits and in nitrates show that the oxygen depleted and nitrate rich thermocline water is lifted up the slope by concurrent upwelling processes. Clearly the current strength increases periodically throughout the year with a repetition rate which is remarkably consistent for oceanic motion (Fig. 2). The period is $91 \pm 20 \mathrm{~d}$ and the oxygen and nitrate data show that during each intensification of the East Australian Current upwelling occurs on the slope. There is no link between these upwelling favourable current intensifications and the seasonal wind pattern which consists for 8 mo of SE Tradewinds and for 4 of NE Monsoons. The periodicity is a boundary current phenomenon closely akin to the boundary current fluctuations of $70 \mathrm{~d}$ period near the Queensland-New South Wales border and the more southerly ones of period 90 to $175 \mathrm{~d}$ (Hamon and Kerr, 1968; Garrett, 1979).
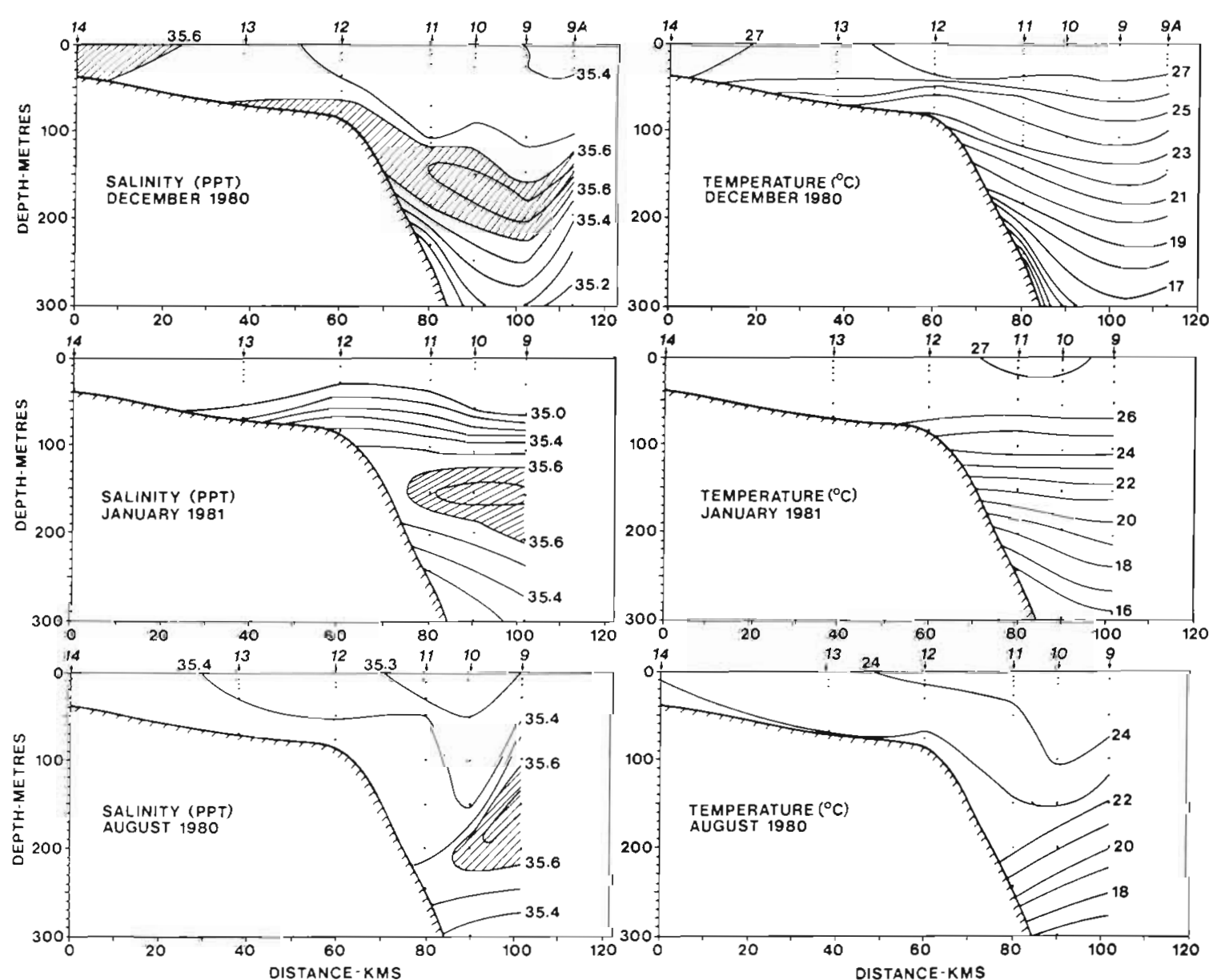

Fig. 3. Vertical sections for salinity and temperature during an upwelling cycle (Top-day 340), a quiescent period (Centre-day 374 ) and during a winter cascade (Lower-day 220). Distance is measured from the outer edge of the Lagoon 
Thermohaline fields from vertical sections (Fig. 3) during a peak of upwelling (Day 340, December), a nearly zero slope current (Day 374, January 1981) and a peak of downwelling (Day 220, August) exemplify modes of exchange of outer shelf and slope waters. Wyrtki (1962) calls the high salinity layer at $150 \mathrm{~m}$ depth Subtropical Lower Water (SLW). It is identified by a salinity of $35.7 \mathrm{ppt}$ and a temperature of $21.5^{\circ} \mathrm{C}$ and extends throughout the western South Pacific Ocean. During upwelling the isopleths slope strongly upwards and SLW intrudes along the bottom, producing density stratification on the shelf. The intermediate January example has SLW lying horizontally against the slope with a suggestion of a mild upwelling in that the isotherms are mildly sloped upwards. The August situation has SLW depressed against the slope by a winter cascade down the slope of cool, oxygenated, somewhat saline shelf water. We saw this cascading only once with clarity and its frequency remains an open question. On the other hand, each time the cur-

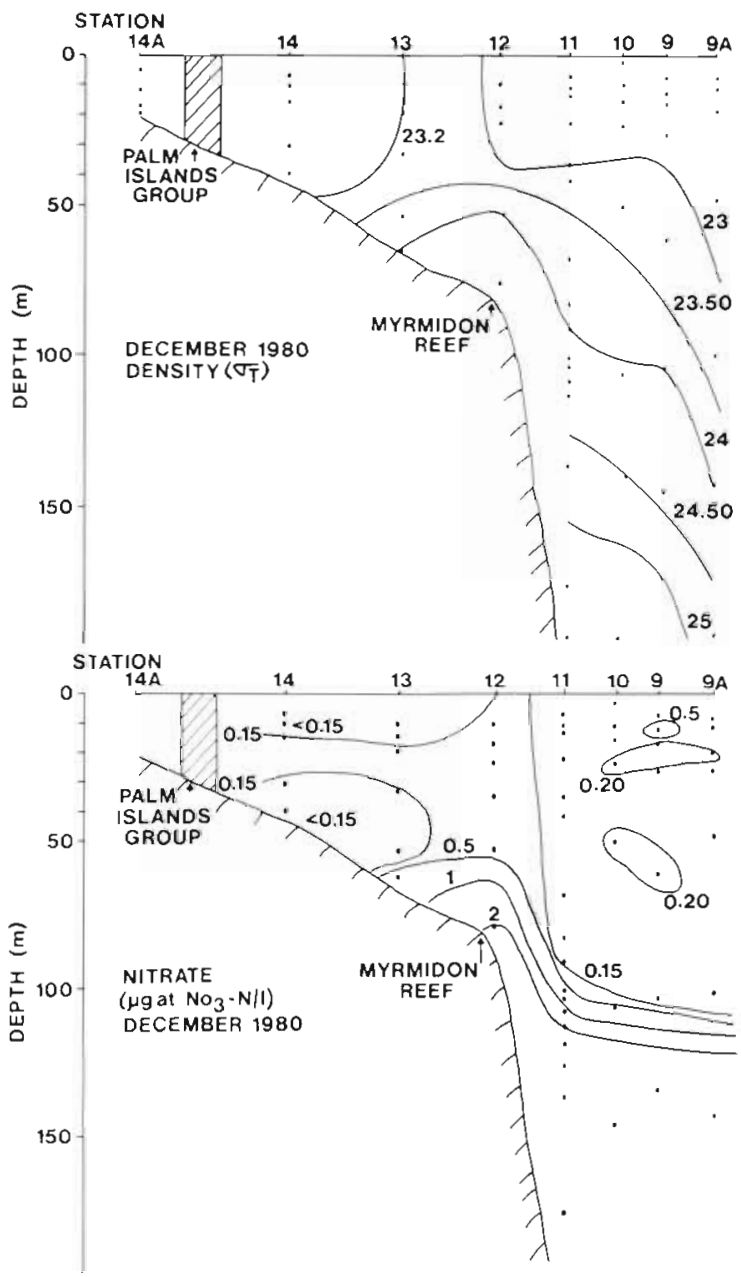

rent intensified over the slope the shelf break and outer shelf were flooded with cool nutrient rich water (e. g. Fig. 4).

Nutrients and associated biological tracer distributions from the Lagoon to the deep-sea frequently reflect a weak density front we see on sigma-t sections near the shelf break (e. g. Fig. 4). This illustrates the return upper water circulation both predicted theoretically by Csanady (1973) and Garrett (1979) and observed in other upwelling ecosystems (Treguer and LeCorre, 1979). There is evidence for closure of the shelf circulation in Fig. 4 as well by weak vertical circulation near the shelf break (Mooers et al., 1976; Treguer and LeCorre, 1979). The oxygen deficit (Fig. 4) in bottom water at the shelf break shows the origin of the intruding water is depleted thermocline water from a layer about $125 \mathrm{~m}$ depth with a mean deficit of $1.3 \mathrm{mg} \mathrm{O} \mathrm{O}_{2} \mathrm{1}^{-1}$. Similarly, nitrate isopleths are traced back to a deep-sea depth band around $125 \mathrm{~m}$, just above the core of SLW. The nitrate values in upwelled
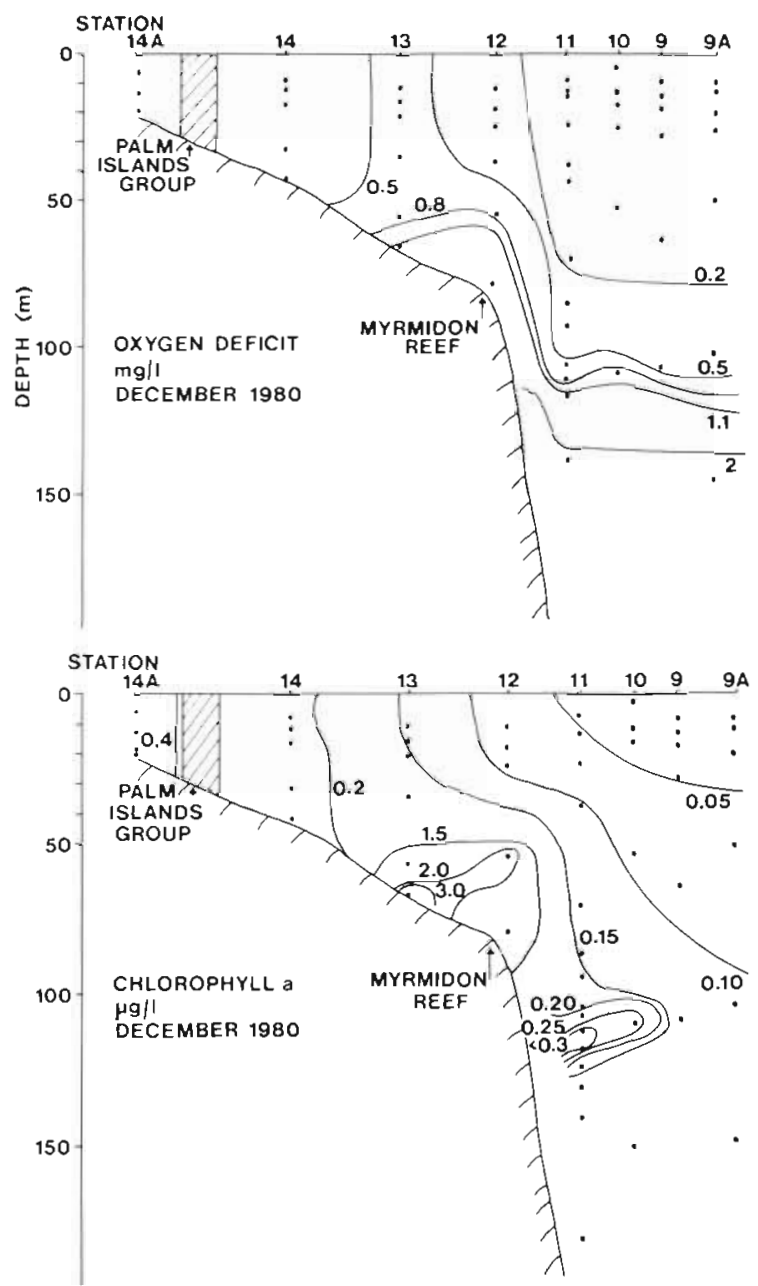

Fig. 4. Vertical sections for density (sigma-t), oxygen deficit, nitrate and chlorophyll a (Phytoplankton) during an East Australian Current intensification (Day 340; Figs. 2 and 3) 
slope water were up to $3 \mu \mathrm{g}$ at $1^{-1}$ at the shelf break and were consistently an order of magnitude higher on the outer shelf during upwelling than concentrations in the unstratified Lagoon. Chlorophyll concentrations were also increased manyfold and reflect phytoplankton development. A patch of chlorophyll rich water was consistently found in the thermocline against the slope (e. g. Fig. 4) and is a common feature of oceans where, given the light, phytoplankton develop close to a nutrient source. The sharp transition on going inshore between nitrate rich and chlorophyll poor bottom water to nitrate poor and chlorophyll rich bottom water (near Station 13 in Fig. 4) is another feature of these upwellings. The position of the transition from nitrate to chlorophyll did not vary markedly from cruise to cruise. Nitrate levels at the shelf break are not a good indicator for upwelling amplitude; we found primary production was frequently very rapid there (e. g. Fig. 4). Ammonia was consistently below the detection threshold on all cruises whereas in large scale eastern boundary upwellings, concentrations up to $2.5 \mu \mathrm{g}$ at $\mathrm{NH}_{4} \mathrm{l}^{-1}$ are found as the result of decomposition of phytoplankton organic matter (Treguer and LeCorre, 1979). The low levels we find suggest a fast turnover in recycling of excreted or released ammonia.

Darwin's question has perhaps been answered for the reefs near the shelf break: mesoscale intensifications of the East Australian Current over the slope produce upwelling in an Ekman layer on the slope (Garrett, 1979) which presents inorganic nutrients directly to the shelf break. The coherence of the $90 \mathrm{~d}$ period suggests that in the evolutionary sense the outer reefs near the shelf break can rely on a perennial, periodic supply of dissolved or particulate nutrients. Long-period upwelling on the slope is produced at this latitude $\left(18.5^{\circ} \mathrm{S}\right)$ by intensifications of the East Australian Current. Similar periodicities are encountered along the New South Wales coast as well (70 d near $27^{\circ} \mathrm{S}$ varying to $90-175 \mathrm{~d}$ between $27^{\circ}$ and $32^{\circ} \mathrm{S}$ ) and are produced by the same mechanism (Garrett, 1979). The mesoscale deep-sea baroclinic fields which generate the periodicities are well documented as structurally similar along the entire east Australian coast (e. g. Scully-Power, 1973; Pickard, 1977) to $34^{\circ} \mathrm{S}$ (Andrews et al., 1980). It is highly probable therefore that tropical upwelling enrichment of the shelf break occurs along the entire Great Barrier Reef. Whether shelf break water moves inshore or not is another question.

The shelf in the study region is, on average, $100 \mathrm{~km}$ wide with the reefs occupying the mid to outer shelf region. There are few reefs in the Lagoon which occupies the region from the shore to the mid shelf (where the matrix of reefs begins). According to Garrett's (1979) theory upwelling on a wide shallow shelf with the stratification we observe will only penetrate about 5 to $10 \mathrm{~km}$ inshore of the shelf break. This is upwelling induced by a boundary current over the slope. But we frequently see upwelling intrusions affecting temperature, salinity and primary production (e. g. Figs. 3 and 4) much further inshore and, as we
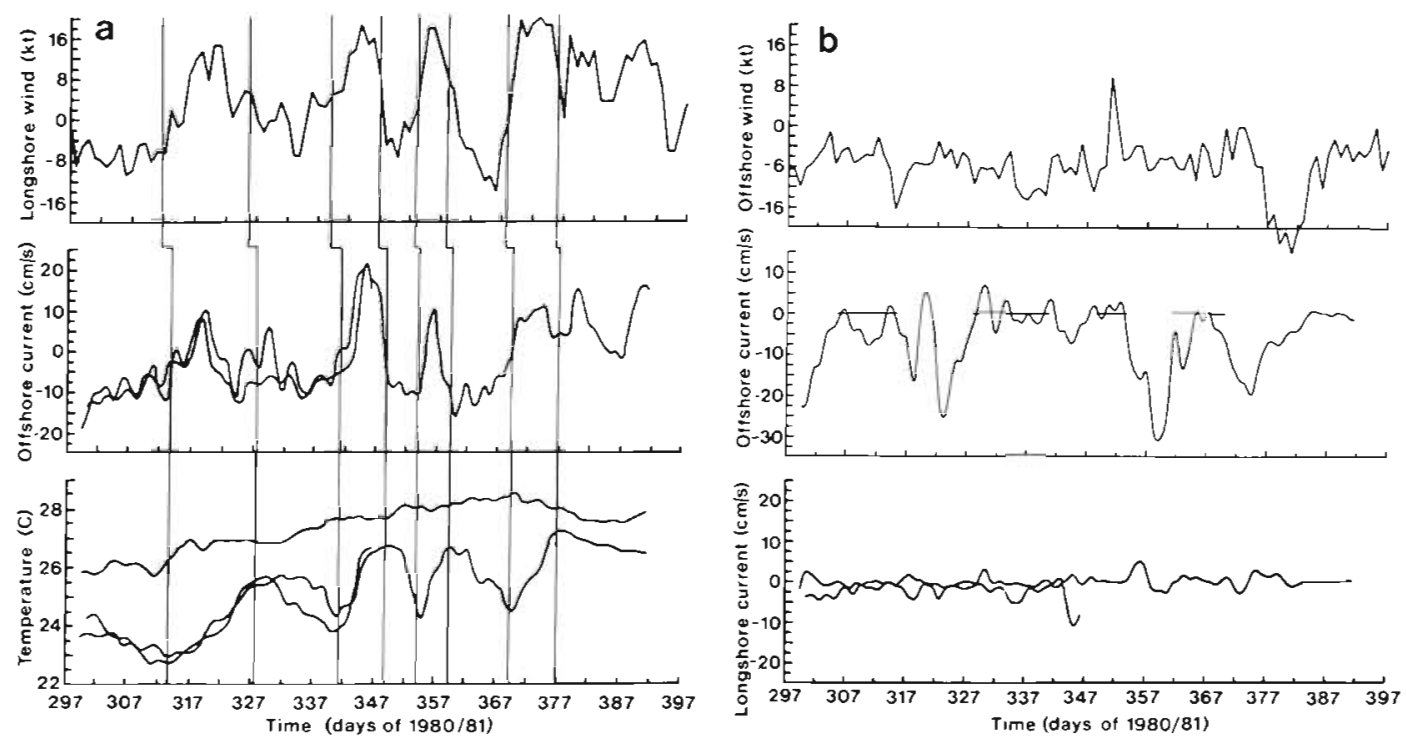

Fig. 5. Time series with tidal signals filtered out. (a) Longshore wind component (top), offshore components of bottom currents (centre), surface and bottom temperatures (lower). The shorter series are from bottom near Rib reef, the longer from near Pith reef. The warmer of the temperature traces is from near-surface, near Pith reef. Vertical lines show subjective correlations. (b) Offshore wind component (top), offshore component of near-surface current from near Pith reef (centre), longshore components of bottom currents from near Pith and Rib reefs (lower) 
shall now show, as far as the outer edge of the Lagoon. These are bottom upwelling intrusions which can be shown to move inshore under wind action.

\section{The Mid Shelf}

The question of biological importance is how far and how quickly the upwelled water spreads shorewards through the reefs of the mid shelf towards the Lagoon. Temperatures $10 \mathrm{~m}$ above the bottom and $10 \mathrm{~m}$ below the surface near Pith Reef (Fig. 5 a) during the last shelf break upwelling cycle (Fig. 2) show 4 marked cooling events where bottom water temperature is depressed some 2 to $3 \mathrm{C}^{\circ}$ below the long term (seasonal) trend. These cold events do not penetrate upwards into the surface layer where the temperature is smooth, so they are bottom intrusions extending inwards from the continental slope. Pith Reef and Rib Reef bottom temperatures are so well correlated that we conclude the intrusions extend across the entire $60 \mathrm{~km}$ zone of reefs. A comparison of bottom temperatures and currents in Fig. 5 a shows the alternate cooling and heating in the thermocline is produced by alternate surges of bottom currents onshore and offshore, averaging $10 \mathrm{~cm} \mathrm{~s}^{-1}$. The bottom surges are a forced response to the reversals in the longshore component of the wind, with a poleward wind producing an onshore surge and the ocean response lagging the wind by $2 \mathrm{~d}$. Currents at $10 \mathrm{~m}$ depth near Pith Reef (Fig. 5 b) showed a steady current flowing onshore with a superimposed oscillatory (mid-column) component. The mid-column surges were opposed to (i. e. balanced according to the theory of Janowitz and Pietrafesa) the oscillatory bottom surges. The steady onshore current was probably forced by the steady $4 \mathrm{~m} \mathrm{~s}^{-1}$ wind (Fig. 5 b) blowing onshore. Since the current meter was near the surface wind driven layer the amplitude of the mid-column flow is uncertain, but lay in the range $10 \pm 5 \mathrm{~cm} \mathrm{~s}^{-1}$. Bottom surges have a period in Fig. 5 a between 12 and $25 \mathrm{~d}$ and can advect nutritionally rich shelf break water at least $55 \mathrm{~km}$ inshore and possibly occasionally into the Lagoon but certainly across the entire zone of reefs. This water would be advected polewards through the reefs some 10 to $30 \mathrm{~km}$ during one cycle by the longshore flow shown in Fig. 5 b. Through the year of hydrographic sampling, the Lagoon was rarely stratified except near the surface after calm periods; the zone of reefs was mostly stratified by a thermocline created by bottom intrusions.

Why is the Lagoon unstratified? We propose 3 contributing reasons. Firstly, the shelf slopes continuously from the shore to the shelf break (e. g. Fig. 4) so tidal mixing and wind stirring increases shoreward from the shelf break. Secondly, the shoreward speed of the cold upwelling intrusions is such that during an onshore event they cannot penetrate well into the Lagoon to stratify it. Thirdly, there are longshore low frequency currents in the Lagoon to mix the fluid horizontally (Wolanski and Bennett, 1982) which are not present in Fig. $5 \mathrm{~b}$ for the mid to outer shelf region. The combination of the limit to onshore travel of the upwelling intrusions with mixing decreasing offshore from the coast produces a region which is mostly unstratified vertically (known as the Lagoon) and a region which is mostly stratified vertically (known as the Great Barrier Reef)

Andrews (1982) has discussed how widespread these wind driven upwelling intrusions are in the study zone of Fig. 1 and has shown for example that the cross shelf

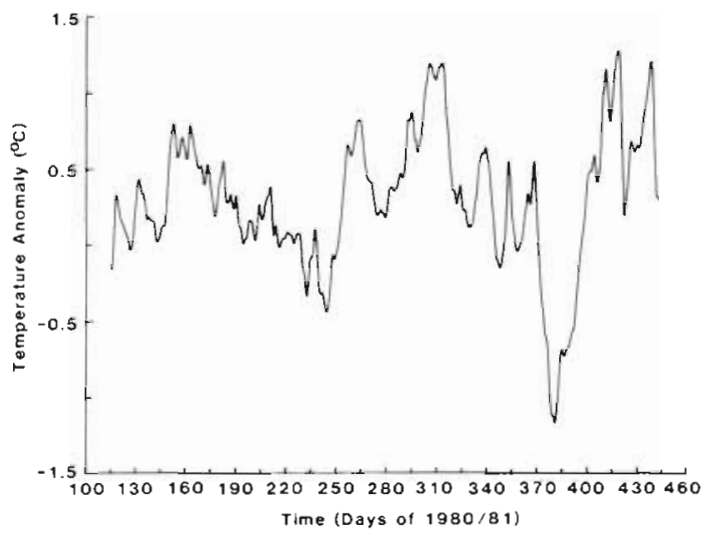

Fig. 6. Deviation of temperature from the seasonal trend in the reef flat of Davies reef. Measurements taken at the bottom of a $20 \mathrm{~m}$ deep, $100 \mathrm{~m}$ diameter hole. Tidal signals filtered out

temperature fronts are coherent at 3 sites: Pith Reef, Davies Reef and Old Reef (19.4 $\left.{ }^{\circ} \mathrm{S}, 148.1^{\circ} \mathrm{E}\right)$. These span about a $200 \mathrm{~km}$ zone of reefs in the longshore direction so it is reasonable to assume that the entire zone is inundated periodically by wind driven bottom surges. This bottom water is transmitted to the living coral of reefs by tides and waves forcing localised upwelling along reef frontal topographic discontinuities as described by Roberts et al. (1975). To establish this final link we released dye deep on the front of Davies Reef, central to the study zone, in winds from 0 to $8 \mathrm{~m} \mathrm{~s}^{-1}$. The dye consistently entered the reef through fissures and canyons along the crest and spread over the reef flat. The temperature in a $20 \mathrm{~m}$ deep lagoon in the Davies Reef flat was monitored for 11 mo. The trace in Fig. 6 was produced by removing annual trends and tidal fluctuations and shows the overflowing of successive cold fronts, year round, with amplitudes of from 0.2 to $1.5 \mathrm{C}^{\circ}$. The Pith Reef and Davies Reef temperatures are very highly correlated $\left(r_{12}=0.91\right.$ with 90 degrees of freedom) and Fig. 6 has a 
dominant periodicity in a band around $30 \mathrm{~d}$, with subsidiary bands around $4 \mathrm{~d}$ in summer and $8 \mathrm{~d}$ in winter (Andrews, 1982). There is a furthor subsidiary band near $125 \mathrm{~d}$ but the records are not long enough to show whether this oscillation is coherent with the slope upwelling oscillation in Fig. 1.

In summary, wind driven upwelling intrusions occur throughout the year and throughout the zone of reefs in Fig. 1, with temperature showing the cold fronts are confined in the thermocline (compare surface and bottom temperatures near Pith Reef; Fig. 5 a) except near topographic discontinuities (Davies Reef flat; Fig. 6).

So far we have a mechanism for presenting nutrients from the deep sea to the shelf break. This is upwelling forced in a bottom Ekman layer on the continental slope by the waxing East Australian Current. We also have a mechanism, wind forcing, for pumping the nutrients (or their primary and secondary products) inshore in a bottom Ekman layer on the continental shelf. We also have a mechanism, localised tidal and wave driven upwelling, for delivering the nutrition from deep shelf ecosystems to reef ecosystems. We now consider how much nutrition (dissolved and or particulate) is delivered to the shelf ecosystems.

\section{Nutrient Concentrations}

Water chemistry results from the monitoring cruises are summarised as a perspective for calculating nutrient fluxes. Chlorophyll concentrations on the shelf in the bottom $20 \mathrm{~m}$ have a mean of $0.4 \mathrm{mg} \mathrm{m}^{-3}$ at the inshore stations and a mean of $0.8 \mathrm{mg} \mathrm{m}^{-3}$ at the offshore stations on the shelf in Fig. 1, whereas the top $15 \mathrm{~m}$ has a constant (annual) mean near $0.3 \mathrm{mg} \mathrm{m}^{-3}$. Chlorophyll variability with time is higher in the bottom layer than in the top layer. There is no apparent seasonal cycle and the average variance of the bottom layer is $1.9 \mathrm{mg} \mathrm{m}^{-3}$ while for the top it is $0.5 \mathrm{mg} \mathrm{m}^{-3}$. Nitrate was frequently undetectable (less than $0.05 \mu \mathrm{g}$ at $1^{-1}$ ) at inshore stations while the mean and variance at offshore stations is respectively 0.4 and $1.2 \mu \mathrm{g}$ at $\mathrm{l}^{-1}$. Nutrients from land runoff do not enter the study site. Runoff is monsoonal and in this region is confined within $30 \mathrm{~km}$ of the coast by a saline front in a north flowing coastal current (Wolanski and Jones, 1981) far from the zone of reefs. Inorganic phosphorus was always below $0.6 \mu \mathrm{g}$ at $1^{-1}$ so the calcification rate of coral would not be affected; calcification is retarded for levels above $2 \mu \mathrm{g}$ at $1^{-1}$ (Kinsey and Davies, 1979). We found upwelling intrusions have a nitrogen to phosphorus ratio near 10 and nitrogen was relatively depleted, indicating regeneration is in an early phase (Calvert and Price, 1971).
Below the surface mixed layer, nitrogen as nitrate regresses linearly on temperature for temperatures above $12{ }^{\circ} \mathrm{C}$ and for stations beyond the shelf break. The relation does not hold on the shelf because primary production depletes nitrate. The relation, independent of season is

$$
\mathrm{N}-\mathrm{NO}_{3}=29.7-1.20 \mathrm{~T}\left(\mu \mathrm{g} \text { at } \mathrm{l}^{-1},{ }^{\circ} \mathrm{C}\right)
$$

The correlation coefficient is -0.95 and there are 227 data points so the relation is highly significant and can be used to calculate the nitrogen concentration at the shelf break (from nitrate but not necessarily as nitrate) from temperature during upwelling.

The total picture which emerges is of a waxing and waning concentration of inorganic plus organic nitrogen at the shelf break. The period is $90 \mathrm{~d}$. These nutrients are pumped inshore by a wind forced oscillatory bottom current and very rapidly progress to phytoplankton. The amplitude and period of the bottom current are approximately $10 \mathrm{~cm} \mathrm{~s}^{-1}$ and 12 to $25 \mathrm{~d}$. The physical model of wind driven intrusions by Janowitz and Pietrafesa (1980) predicts a return flow, for mass continuity, in the layers above the upwelling intrusion. Current meter data in Fig. 5 b support this. The model is highly idealised, of course, so we checked the horizontal and vertical distributions of chemical tracers with some finely gridded cruises over a necessarily more limited region than the whole study site.

In Fig. 7 we present the results from one such cruise in March 1981 based on 41 stations. The 50,100 and $200 \mathrm{~m}$ isobaths parallel to the continental slope provide the frame of reference with intrusions expected across the isobaths and the East Australian Current flowing in deep water parallel to them (to south east). Reefs are enclosed by their $30 \mathrm{~m}$ isobath but of course, they protrude to the surface. The area is not well surveyed and the maps are imprecise. Nitrate is quickly utilised after crossing the $100 \mathrm{~m}$ isobath so we have displayed the depth of the constant surface $6 \mu \mathrm{g}$ at $1^{-1}$ to show the deep sea sources (Fig. 7 a). The intruding waters, in this example, have a lesser concentration. The depth of the surface varies between 160 and $210 \mathrm{~m}$ and there seems to be an internal wavelike perturbation with separation between the three enriched peaks of $20 \mathrm{~km}$. The 2 nearer shore peaks appear to connect to the shelf break by enrjched tongues. Bottom salinities and temperatures (respectively Figs, $7 \mathrm{~b}$ and $\mathrm{c}$ with the values for the deep ocean corresponding to $75 \mathrm{~m}$ depth) show that these nitrate rich bands connect to cold, saline, bottom intrusions on the shelf. The upwelling intrusion bifurcates around the Slashers group of reefs and is confined by the local (reef) topography to the NW and SE and by the inshore $50 \mathrm{~m}$ line which represents the farthest 
a

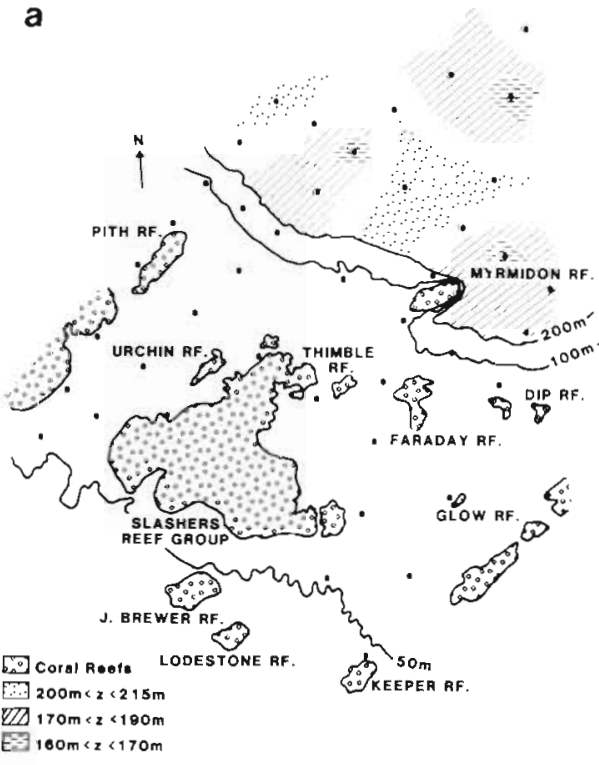

c

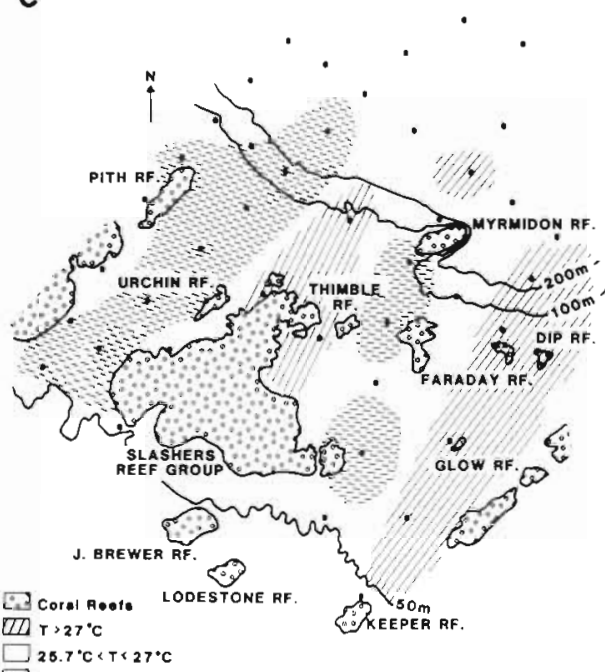

俩 $T>27^{\circ} \mathrm{c}$

$28.7{ }^{\circ} \mathrm{C}<T<27^{\circ} \mathrm{C}$

e

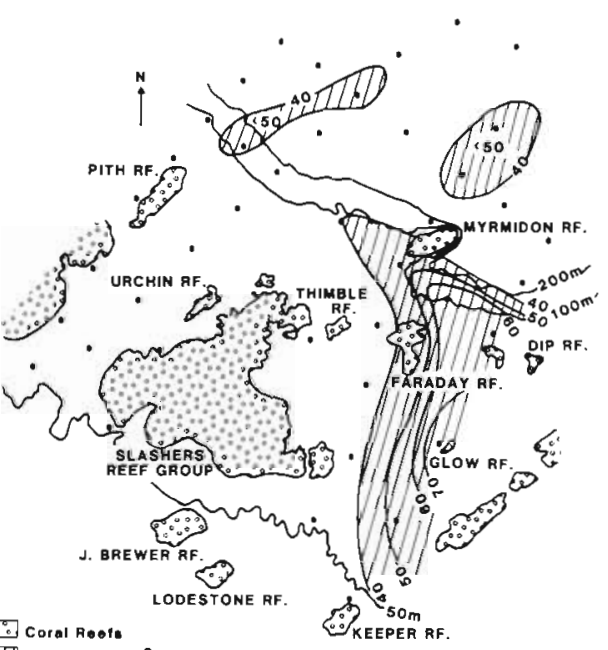

b

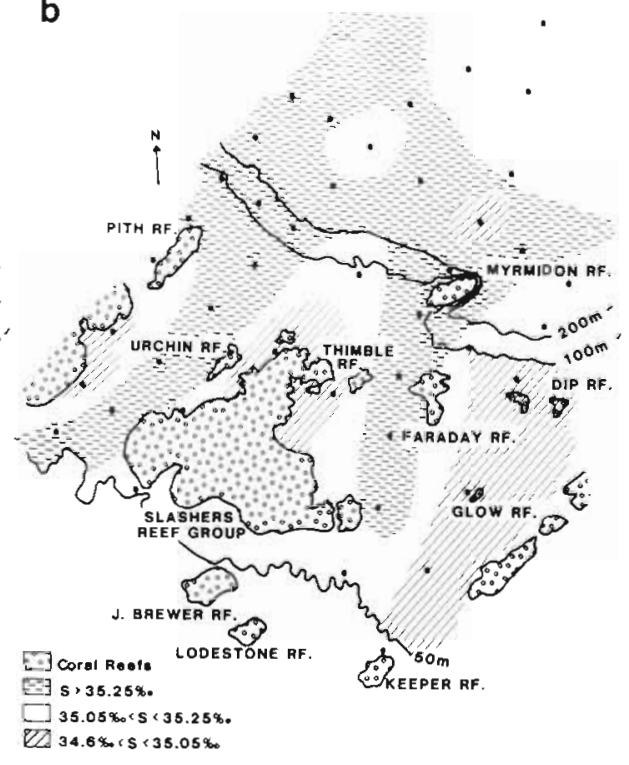

d

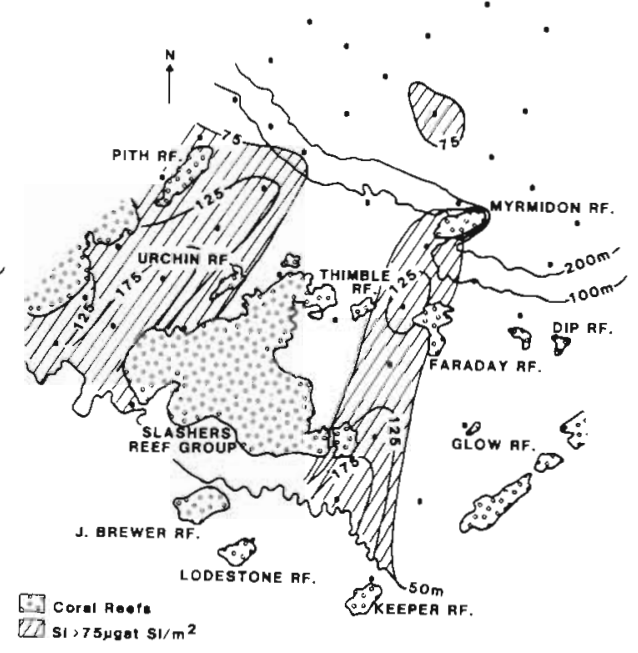

Fig. 7. Distribution of properties during upwelling in March 1981. (a) Nitrate as depth of $6 \mu \mathrm{g}$ at $1^{-1}$ surface showing 3 deep sea sources of which 2 protrude to the shelf break. (b) Bottom salinity and (c) bottom temperature showing a cold, saline intrusion bifurcating around the Slashers group. (d) Upper layer integrated silicate showing return offshore surface flow above the intrusions. (e) Vertically integrated chlorophyll a showing phytoplankton standing crop in the older intrusion 
seaward extremity of the outer Lagoon. Just as the 2 cold, saline tongues on the shelf are opposite deep-sea sources of nitrate, so also is the warmer, fresher, central tongue on the shelf opposite a nitrate poorer deep-sea region. We do not know whether to attribute this banded structure to purely onshore flow or to onshore flow of cold water around a central offshore flow of warm water. The silicate data (Fig. 7 d) help to clarify this.

The top of the thermocline had a variable depth and it was also difficult to separate upper and lower water unambiguously on the basis of chemical tracers. We found that the $28^{\circ} \mathrm{C}$ isothermal surface coincided reasonably with the layer of maximum density gradient. We also found that Lagoon water was rich in silicates at this period of the year and that shelf water warmer than $28^{\circ} \mathrm{C}$ was richer in silicates than the deeper layers. In Fig. $7 \mathrm{~d}$ we present the values of vertically integrated silicate above the isothermal $28^{\circ} \mathrm{C}$ surface. The return circulation in the upper layer predicted by Janowitz and Pietrafesa's model is clearly shown by the 2 tongues extruding seaward above the cold, saline upwelling intrusions of Figs. $7 \mathrm{~b}$ and $c$. The central band is very low in silicates.

Both the onshore flow and the return flow in the upper layer seem to be topographically steered by the local reef distribution and, since the south east feature is more patchy, both in lower thermohaline distributions and upper silicate distributions than the north west feature, the former is either older or weaker than the latter. The effect of the upwelling intrusions on phytoplankton standing crop is shown by the integrated chlorophyll values in Fig. 7 e. Intense phytoplankton development has occurred in the south east intrusion and extends up to the Lagoon. The development of phytoplankton in the south east suggests that this intrusion is the older of the two. It seems (Fig. 7) that any reef between the shelf break and the Lagoon will be influenced by dissolved or by particulate nutrients periodically.

\section{Nutrient Fluxes}

We are now in a position to estimate the nutritional input across the shelf break initiated by nitrate fluxes up the continental slope. There are 3 steps. First, we need to know the seasonal sinusoidal cycle of temperature of Shelf Break Water so we can calculate nitrogen concentrations there from the linear regression relation. Second, we need to modulate this annual cycle to account for a $90 \mathrm{~d}$ sinusoidal upwelling cycle (Fig. 2). Third, we need to estimate how much of this nitrogen is pumped inshore from the shelf break by bottom surges. This too is approximated by a sinusoid.
We define Shelf Break Water as the layer within $30 \mathrm{~m}$ of the sea floor in a slice of ocean between the $70 \mathrm{~m}$ and $200 \mathrm{~m}$ isobaths. To define the seasonal cycle of Shelf Break Water temperature we took the hydrology data from 15 cruises over $450 \mathrm{~d}$ and calculated the mean and standard deviation of temperatures in the layer for each cruise. The results are presented in Fig. 8. The wide deviation on each cruise and the perturbation from cruise to cruise in the means make it difficult to quantify the seasonal cycle. The a priori knowledge of the times of summer and winter allow us

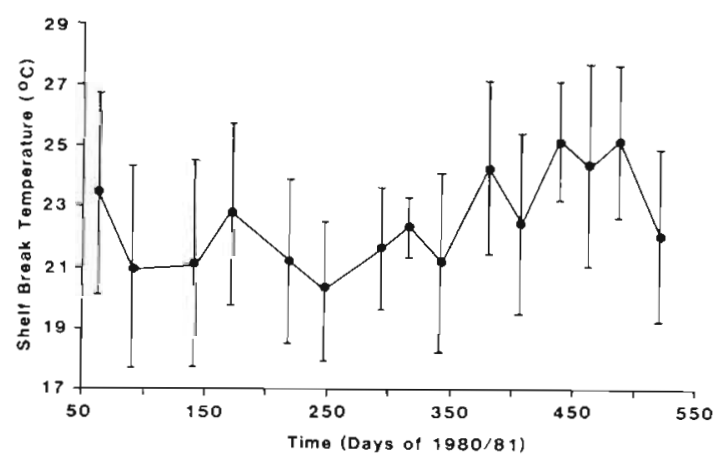

Fig. 8. Mean temperatures of Shelf Break Water showing a weak seasonal cycle of $\pm 2 \mathrm{C}^{\circ}$ about an annual mean of $22.5^{\circ} \mathrm{C}$. Bars are 2 standard deviations apart. Each group is from one cruise

to estimate and annual range of $\pm 2 \mathrm{C}^{\circ}$ about a mean of $22.5^{\circ} \mathrm{C}$. The period of this oscillation is $365 \mathrm{~d}$. To this is added an oscillation of $\pm 2 \mathrm{C}^{\circ}$ and period $90 \mathrm{~d}$ to account for upwelling intensifications (Fig. 2). Using the regression relation to convert to nitrogen at the shelf break gives concentrations there between 0.3 and $9.9 \mu \mathrm{g}$ at $\mathrm{l}^{-1}$.

This dissolved and particulate nutrient is pumped in from the shelf break with a speed up to $10 \mathrm{~cm} \mathrm{~s}^{-1}$ and a periodicity of $30 \mathrm{~d}$. We previously gave 12 to $25 \mathrm{~d}$ as the period from summer data but Andrews (1982) shows $30 \mathrm{~d}$ is appropriate for an all-year average. The thickness of the Ekman layer which carries this nutrient flux is found by inspecting near bottom temperature profiles obtained from expendable bathythermograph probes. It is about $10 \mathrm{~m}$. The flux of nitrogen into the shelf ecosystems through a $10 \mathrm{~m}$ thick bottom layer was calculated numerically over many annual cycles and averaged. The result is $0.02 \mu \mathrm{g}$ at $\mathrm{cm}^{-2} \mathrm{~s}^{-1}$.

If we assume the primary and secondary production is spread across a $50 \mathrm{~km}$ zone of reefs, which is as far as the intrusions generally penetrate, and throughout the water column with an average depth (Fig. 4) of $60 \mathrm{~m}$, then the annual nitrogen (from nitrate, not as nitrate) input is about $20 \mu \mathrm{g}$ at $l^{-1}$. This is an enormous input for tropical waters.

Phytoplankton fix between 10 and $20 \mathrm{gC} \mathrm{m}^{-2} \mathrm{yr}^{-1}$ in 
the open waters of the Great Barrier Reef according to Sorokin (1973). Using a carbon to nitrogen ratio of 7 (Redfield et al., 1963) the nitrogen input (20 $\mu \mathrm{g}$ at $\mathrm{l}^{-1}$ in $60 \mathrm{~m}$ depth) could potentially support a carbon fixation of about $175 \mathrm{gC} \mathrm{m}^{-2} \mathrm{yr}^{-1}$, which is an order larger than the carbon fixed by phytoplankton. We can consider coral reefs at the other end of the primary productivity scale and use Kinsey's (1982) estimate for entire reefs (not just reef flats) of $1,500 \mathrm{gC} \mathrm{m}^{-2} \mathrm{yr}^{-1}$. Reefs in the study site cover between 5 and $10 \%$ of the shelf there, so our shelf-wide estimate of $175 \mathrm{gC} \mathrm{m}^{-2} \mathrm{yr}^{-1}$ demonstrates that upwelling is clearly significant for Great Barrier Reef ecosystems. A statement of how much growth will in fact occur awaits experiments on the pathways between deep water shelf and reef ecosystems and an assessment of the net nutritional requirements of reefs.

\section{CONCLUSIONS}

The scale of physical mechanisms which combine to deliver dissolved and particulate nutrients to the Great Barrier Reef ecosystems is very broad. Planetary wave perturbations in the East Australian Current produce a 90-d oscillatory intensification which pumps nutrients to the shelf break from a bottom Ekman layer on the slope. An oscillatory longshore and steady onshore component of the wind respectively pump the nutrients inshore and advect them poleward through the outer $60 \mathrm{~km}$ reef zone. The NE Monsoons and SE Trades supply the steady wind stress but a wide band modulation of 12 to $25 \mathrm{~d}$ (year round mean is $30 \mathrm{~d}$; Andrews, 1982) is produced by the atmospheric highs and lows which drift along the Southern Ocean continental interface. We cross - correlated the strength of the summer thermocline (Fig. 5) near Pith reef with concurrent atmospheric pressure taken $2700 \mathrm{~km}$ south in Tasmania to highlight the link. The high pressure cells over Tasmania turned out to lead the onset of cooling off Townsville by $10.5 \mathrm{~d}$, and with a correlation coefficient of 0.5 (100 d series). The final link in the physical forcing is the delivery of the dissolved and particulate nutrients to reefs directly out of the thermocline by upwelling induced by tides and waves. Biological transfer as well as turbulent transfer to the surface will of course also take place progressively as the intrusions age.

The loose correlation of regions of prolific reef growth with steepness of the continental slope (Maxwell, 1968; Maxwell and Swinchatt, 1970) is probably a reflection of upwelling amplitude and its observed (Orr, 1933) and theoretical correlation with shelf and slope topography (Csanady, 1973; Garrett, 1979; Janowitz and Pietrafesa, 1980). Mean nutrient levels and variabilities decrease poleward along the shelf break of our study site and so does the bathymetric gradient. Further north, where the continental slope steepens markedly, the reefs are compacted to the point where lateral water exchange is severely limited. The exact nature of the link between latitudinal reef proliferation and the submarine shelf and slope topography needs to be resolved.

Longitudinal heterogeneity depends more on ecosystem responses to different food climates. Transect studies of species distribution patterns show a marked longitudinal gradient across our study site (scleractinian corals, T. Done; reef fishes, D. Mc B. Williams; pers. communications). We did not measure zooplankton but we observed a change shoreward from inorganic nutrient to phytoplankton which presumably progresses to zooplankton (Bishop et al., 1980; Paffenhöfer, 1980). Particulate organics can be directly assimilated by reef filter (Lewis, 1976) and suspension (Reiswig, 1971) feeders, including corals and can be transferred to the benthos by fish (McCloskey and Chesher, 1971). Indeed, diatom and zooplankton densities can be reduced by $60 \%$ in traversing reef flats (Glynn, 1973). We are not surprised therefore, to find the ecosystem species distributions reflecting a cross shelf adaptation biased progressively towards inorganic nutrients, phytoplankton and zooplankton.

The world distribution of coral reefs shows a marked concentration in major tropical current systems; e. g. Somali Current, Equatorial Current system, Indonesia, NW Australia, NE Australia, Carribean, etc. On the other hand, major upwelling systems exhibit a great variety in secondary production. The present case is a western boundary upwelling where the scales of the wind field and of the East Australian Current encompass the entire length of the Reef. We are satisfied therefore that the Great Barrier Reef is an ecological response to tropical upwelling as suggested by Orr (1933) and propose as a general working hypothesis that a large part of the heterogeneity of coral reef ecosystems is supported by tropical upwelling. This notion has existed since 1933 when Orr concluded his remarks on planktonic succession in the Great Barrier Reef with the generalisation, 'It would be interesting in this connection to investigate the seas in the neighbourhood of oceanic coral islands for upwelling'.

Assuredly the reefs of the Great Barrier Reef are influenced by the upwelling mechanisms we have demonstrated. The reefs have grown because they are supplied with particulate matter. The reefs themselves modify the current system as they grow. So there is a feedback system, with the flow patterns modifying the bottom and the bottom modifying the flow patterns. We wonder, finally, if this interplay between nature's physical and biological forces tends towards a steady, or nearly steady balance. 
Acknowledgements. We thank Dr J. R. Strickler for his constant support. Dr. J. Church (CSIRO) contributed 4 points to Fig. 2. Mr. A. Mitchell, Mrs. S. Ball, Ms. V. Ryle and the AIMS Field Group collected most of the data for us. For criticism we thank our colleagues at AIMS. This work was supported by the Australian Institute of Marine Science.

\section{LITERATURE CITED}

Andrews, J. C. (1982). Thermal waves on the Queensland shelf. Unpublished manuscript (submitted to Aust. J. mar Freshwat. Res.)

Andrews, J. C., Lawrence, M. W., Nilsson, C. S. (1980). Observations of the Tasman Front. J. Phys. Oceanogr. 10: $1854-1869$

Atkinson, L. P. (1977). Modes of Gulf Stream intrusion into the South Atlantic Bight shelf waters. Geophys. Res. Lett. 4: 583-586

Atkinson, L. P., Paffenhöfer, G. A., Dunstan, W. M. (1978). The chemical and biological effect of a Gulf Stream intrusion off St. Augustine, Florida. Bull. mar. Sci. 28: 667-679

Bishop, S. S., Yoder, J. A., Paffenhöfer, G. A. (1980). Phytoplankton and nutrient variability along a cross-shelf transect off Savannah, Georgia, U.S.A. Estuar. coast, mar. Sci. 11: $359-368$

Blanton, J. (1971). Exchange of Gulf Stream water with North Carolina shelf water in Onslow Bay during stratified conditions. Deep Sea Res. 18: 167-178

Brandon, D. E. (1973). Waters of the Great Barrier Reef province, In: Jones, O. A., Endean, R. (eds.) Biology and geology of coral reefs, Vol. 1, Geology 1. Academic Press, New York, pp. 187-232

Calvert, S. E., Price, N. B. (1971). Upwelling and nutrient regeneration in the Benguela Current, October 1968. Deep Sea Res. 18: 505-523

Csanady, G. T. (1973). Wind-induced baroclinic motions at the edge of the continental shelf. J. Phys. Oceanogr. 3: $274-279$

Daly, R. A. (1934). The changing world of the ice age, Yale University Press, Connecticut

Darwin, C. R. (1842). The structure and distribution of coral reefs, University of California Press, Berkley, California

Darwin, C. R. (1933). Charles Darwin's diary of the voyage of HMS. Beagle. Edited from the manuscript by N. Barlow. Cambridge University Press, London and New York

Dunstan, W. M., Atkinson, L. P. (1976). Sources of new nitrogen for the South Atlantic Bight. In: Wiley, M. (ed.) Estuarine processes, Vol. 1, Uses, stresses and adaptation to the estuary. Academie Press, New York, pp. 69-78

Garrett, C. (1979). Topographic Rossby waves off east Australia: identification and role in shelf circulation. J. Phys. Oceanogr. 9: 244-253

Glynn, P. W (1973). Ecology of a Carribean coral reef. The Porites reef-flat biotope: II. Plankton community with evidence for depletion. Mar. Biol. 22: 1-21

Green, C. W (1944). Summer upwelling north east coast of Florida. Science, N.Y. 100: 546-547

Hamon, B. V. (1968). Temperature structure in the upper $250 \mathrm{~m}$ in the East Australian Current area. Aust. J. mar. Freshwat. Res. 19: 91-99

Hamon, B. V., Kerr, J. D. (1968). Time and space scales of vari- ,ns in the East Australian Current from merchant ship data. Aust. J. mar. Freshwat. Res. 19: 101-106

Janowitz, G. S., Pietrafesa, L. J. (1980). A model and observa- tions of time dependent upwelling over the mid-shelf and slope. J. Phys. Oceanogr. 10: 1574-1583

Kinsey, D. W., Davies, P. J. (1979). Effects of elevated nitrogen and phosphorus on coral reef growth. Limnol. Oceanogr. 29: $935-940$

Kinsey, D. W. (1982). Standards of performance in coral reef primary production and carbon turnover In: Barnes, D (ed.) Perspectives on coral reefs. Australian Institute of Marine Science, Townsville

Lewis, J. B. (1976). Experimental tests of suspension feeding in Atlantic reef corals. Mar. Biol. 36: 147-150

McCloskey, L. R. H., Chesher, B. J. (1971). Effects of manmade pollution on the dynamics of corals reefs. In: Miller, J. W., Van der Walker, J. G., Walker, R. A. (eds.) Scientists-in-the-sea. 1. USA Dept. of Interior, Washington, pp. 229-238

Maxwell, W. P. H. (1968). Atlas of the Great Barrier Reef Elsevier, Amsterdam

Maxwell, W. P. H., Swinchatt, J. P. (1970). Great Barrier Reef regional variation in a terrigenous-carbonate province. Bull. Geological Soc. Am. 81: 691-724

Mooers, C. N. K., Collins, C. A., Smith, R. L. (1976). The dynamic structure of the frontal zone in the coastal upwelling region off Oregon. J. Phys. Oceanogr. 6: 3-21

Orr, J. P. (1933). Scientific report of the Great Barrier Reef expedition. 1928-1929. Br. Mus (Natl. Hist.) II: 37-86

Paffenhöfer, G.-A. (1980). Zooplankton distribution as related to summer hydrographic conditions in Onslow Bay, North Carolina. Bull. mar. Sci. 30: 819-832

Pickard, G. L. (1977). A review of the physical oceanography of the Great Barrier Reef and western Coral Sea. I. The Great Barrier Reef. A.I.M.S. Monographs 2: 1-58

Pomeroy, L. R., Kuenzler, E. J. (1969). Phosphorus turnover by coral reef animals. In: Nelson, D. J., Evans, F. C. (eds.) Proceedings of the 2nd National Symposium on Radioecology. U.S. Atomic Energy Commission TID-4500, pp. $474-482$

Redfield, A. C., Ketchum, B. H., Richards, F. A. (1963). The influence of organisms on seawater. In: Hill, M. N. (ed.) The sea, Vol. 2. Wiley Interscience, London, pp. 26-77

Reiswig, H. M. (1971). Particle feeding in natural populations of three marine demosponges. Biol. Bull. mar. biol. Lab., Woods Hole 141: 568-591

Roberts, H. H., Murray, S. P., Suhayda, J. N. (1975). Physical processes in a fringing reef system. J. mar. Res. 33: 233-260

Rochford, D. J. (1972). Nutrient enrichment of east Australian coastal waters. I. Evans Head upwelling. C.S.I.R.O. Div. Fish. Oceanogr. Tech. Pap. No. 33

Rochford, D. J. (1975). Nutrient enrichment of east Australia coastal waters. II. Laurieton upwelling. Aust. J. mar. freshwat. Res. 26: 233-243

Scully-Power, P. D. (1973). Coral Sea flow budgets in winter. Aust. J. mar. Freshwat. Res. 24: 203-215

Sorokin, Yu. I. (1973). Microbiological aspects of the productivity of coral reefs. In: Endean, R. Jones, O. A. (eds.) Biology and geology of coral reefs, Vol. 2. Academic Press, New York, pp. 17-95

Stefansson, U., Atkinson, L. P., Bumpus, D. F. (1971). Hydrographic properties and circulation in the North Carolina shelf and slope waters. Deep Sea Res. 18: 383-420

Treguer, P., LeCorre, P. (1979). The ratio of nitrate, phosphate and silicate during uptake and regeneration phases of the Moroccan upwelling regime. Deep Sea Res. 26 A: 163-184

Wolanski, E. Bennett, A. F. (1982). Shelf waves and their influence on the circulation around the Great Barrier Reef. Aust. J. mar. Freshwat. Res. (in press) 
Wolanski, E., Jones, M. (1981). Physical properties of the Great Barrier Reef Lagoon waters near Townsville. 1. Effects of Burdekin river floods. Aust. J. mar. Freshwat. Res. 32: 305-319

Wyrtki, K. (1962). The subsurface water masses in the western South Pacific ocean. Aust. J. mar. Freshwat. Res. 13: 18-47
Yonge, C. M., Nicholls, A. G. (1931). Studies on the physiology of corals. $V$ The effect of starvation in light and in darkness on the relationship between corals and zooxanthellae. Sci. Rep. Gt. Barrier. Rf. Exped. 1928-1929. Br Mus. (Natl. Hist.) I: 177-211

This paper was presented by Dr. J. S. Bunt; it was accepted for printing on February 10, 1982 